\title{
SULUH
}

JURNAL BIMBINGAN DAN KONSELING

\section{EFEKTIVITAS LAYANAN KONSELING INDIVIDU DENGAN PENDEKATAN REALITAS UNTUK PEMANTAPAN PEIMINATAN PADA PESERTA DIDIK SMAN- 2 PALANGKARAYA}

\section{Effectiveness Of Individual Counseling Service Approach To Reality For Consolidation Of Learners Specialization SMAN 2 Palangkaraya}

\author{
'Fatmawati, ${ }^{2}$ Karyanti
}

IUniversitas Muhammadiyah Palangkaraya, Jekan Raya, Palangka Raya, Kalimantan Tengah, Indonesia

2 Universitas Muhammadiyah Palangkaraya, Jekan Raya, Palangka Raya, Kalimantan Tengah, Indonesia

\section{ARTIKEL INFO}

Diterima

Desember 2017

Dipublikasi

Februari 2018

*E-mail:

karyantivanesa@gmail.com

\section{ABSTRAK}

Tujuan penelitian ini untuk mengetahui layanan konseling individual SBMT dan OAP dapat memantapkan peminatan peserta didik kelas XI MIPA di SMAN-2 Palangka Raya. Populasi dalam penelitian ini berjumlah 35 orang peserta didik. Jumlah sampel penelitian terdiri dari 2 orang peserta didik. Pengambilan sampel ditentukan dengan teknik Purposive Sampling. Teknik pengumpulan data menggunakan observasi, dan skala pemantapan peminata. Metode yang digunakan adalah pre-eksperimen, teknik analisis data menggunakan One-Sample T Test atau lebih dikenal dengan Pre-Post Design adalah analisis dengan melibatkan dua pengukuran pada subjek yang sama terhadap suatu pengaruh atau perlakuan tertentu. Berdasarkan hasil analisis dan pembahasan di atas, maka dapat disimpulkan bahwa Layanan Konseling Individual dengan Teknik (Wants, Direction, Evaluation, Plan) WDEP dapat memantapkan peminatan pada Peserta Didik di Kelas XI MIPA 3 SMAN-2 Palangka Raya. Hal tersebut didasarkan pada hasil uji One-Sample $\mathrm{T}$ Test, menunjukkan bahwa pemantapan peminatan mengalami peningkatan rata-rata 45 menjadi 74 , dengan jumlah ratarata peningkatan sebesar 29. Artinya "Layanan Konseling Individual Realitas dengan Teknik (Wants, Direction, Evaluation, Plan) WDEP dapat meningkatkan pemantapan peminatan pada Peserta Didik Kelas XI MIPA 3 SMAN-2 Palangka Raya .

Kata Kunci : Konseling realita, Pemantapan Peminatan

Orchid:

\section{ABSTRACT}

The purpose of this study is to find out the individual counseling services of SBMT and OAP can strengthen the interest of students of class XI MIPA at SMAN-2 Palangka Raya. The population in this study amounted to 35 students. The number of research samples consisted of 2 students. Sampling is determined by purposive sampling technique. The data collection technique uses observation, and the scale of stabilization of the audience. The method used is pre-experiment, the technique of analyzing data using One-Sample T Test or better known as Pre-Post Design is an analysis involving two measurements on the same subject against a particular influence or treatment. Based on the results of the analysis and discussion above, it can be concluded that WDEP Individual Counseling Services (Wants, Direction, Evaluation, Plan) WDEP can strengthen specialization in Students in Class XI MIPA 3 of SMAN-2 Palangka Raya. This is based on the results of the One-Sample T Test, indicating that consolidation of specialization has increased by an average of 45 to 74, with an average number of increases of 29. Meaning "Counseling Services Individual Realities with Techniques (Wants, Direction, Evaluation, Plan) WDEP can improve stabilization of interest in Class XI MIPA 3 Students of SMAN-2 Palangka Raya.

Keywords: Reality counseling, Strengthening Specialization 
Jurnal Bimbingan dan Konseling

\section{PENDAHULUAN}

Pendidikan pada dasarnya merupakan proses untuk membantu manusia dalam mengembangkan potensi dirinya sehingga mampu menghadapi setiap perubahan yang terjadi. Tetapi proses pendidikan ini banyak yang mengatakannya sebagai proses belajar mengajar, yang kemudian mempengaruhi jiwa pendidik sehingga yang dilakukannya adalah mengajarkan ilmu pengetahuan saja. Apa yang sering terjadi adalah hanya proses menstransfer ilmu pengetahuan kepada anak didik, soal pembentukan karakter dan moral tidak diutamakan, oleh sebab itu jauhkanlah pemakaian istilah proses belajar-mengajar, dan kembalilah pada istilah proses pendidikan. Adapun penjurusan yang berdasarkan minat dengan tiga pilihan yaitu Matematika, IPA, IPS, Bahasa dan Kebudayaan. Para siswa SMA memilih peminatan sejak duduk dikelas $X$ (I SMA). Seleksi peminatan akandilakukan berdasarkan nilai raport SMP dan wawancara oleh guru Bimbingan dan Konseling

Menurut ABKIN (20I3: 23) Peminatan berasal dari kata minat yang berarti kecenderungan atau keinginan yang cukup kuat berkembang pada diri individu yang terarah dan terfokus pada terwujudkannya suatu kondisi dengan memepertimbangkan kemampauan dasar, bakat, minat, dan kecenderungan pribadi individu. Menurut Panduan bimbingan dan konseling sekolah menengah pertama (2014: 30) Peminatan berasal dari kata minat yang berarti kecenderungan atau keinginan yang cukup kuat berkembang pada diri individu (dalam hal ini peserta didik) yang terarah dan terfokus pada terwujudkannya suatu kondisi dengan memepertimbangkan kemampauan dasar, bakat, minat, dan kecenderungan pribadi individu. Peraturan Menteri Pendidikan Dan Kebudayaan Republik Indonesia (2014:10) Layanan peminatan peserta didik secara khusus ditujukan untuk memberikan kesempatan kepada peserta didik mengembangkan kompetensi sikap, kompetensi pengetahuan, dan kompetensi keterampilan peserta didik sesuai dengan minat, bakat dan/atau kemampuan akademik dalam sekelompok mata pelajaran keilmuan, maupun kemampuan dalam bidang keahlian, program keahlian, dan paket keahlian

\section{METODOLOGI PENELITIAN}

Penelitian ini menggunakan metode penelitian kuantitaif dengan menggunakan teknik skala yang dilakukan secara klasikal. Alasan dilakukan secara klasikal untuk mengetahui permasalahan siswa tentang pemantapan peminatan yang ingin diteliti dan dilkukan konseling, dengan cara mengetahui skor yang mereka jawab di soal skala pemantapan peminatan. Penyusunan skala pemantapan peminatan berdasarkan pengertian peminatan yang dikemukakan Menurut Panduan bimbingan dan konseling sekolah menengah pertama (2014: 30) di antaranya: potensi kemampuan dasar mental, bakat, minat, dan kecenderungan pribadi. Jumlah item yang akan dibagikan adalah 60 item yang terdiri dari 40 favorable dan 20 unfavorable. Format respon dari skala pemantapan peminatan adalah model summated rating scale yang terdiri dari empat pilihan jawaban yaitu sangat setuju (SS), setuju (S), tidak setuju (TS), sangat tidak setuju (STSO

\section{HASIL DAN PEMBAHASAN}

Berdasarkan hasil pengukuran pemantapan peminatan dengan menggunakan skala pemantapan peminatan saat pre-test dan post-test pada subjek penelitian. Data hasil pretest dan post-test pada subjek penelitian di lengkapi dengan deskripsi, perubahan, terapeutik, dan perubahan pada diri peserta didik dari masing-masing peserta didik pada subjek dan berikut adalah hasil pre-test dan post-test subjek penelitian 
Tabel I

Rekaptulasi Skor Pemantapan Peminatan

\begin{tabular}{|c|c|c|c|c|}
\hline \multicolumn{3}{|c|}{ Pre-test } & \multicolumn{2}{|r|}{$\begin{array}{l}\text { Post- } \\
\text { test }\end{array}$} \\
\hline & & & Sko & Katego \\
\hline Subjek & Skor & Kategori & $r$ & ri \\
\hline SBMT & 45 & Sedang & 74 & Tinggi \\
\hline OAP & 49 & Sedang & 65 & Tinggi \\
\hline
\end{tabular}

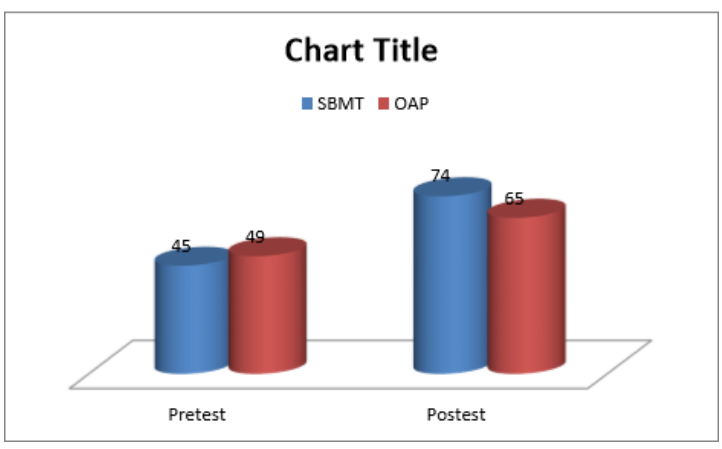

Tabel 2 Hasil Uji T

One-sample test

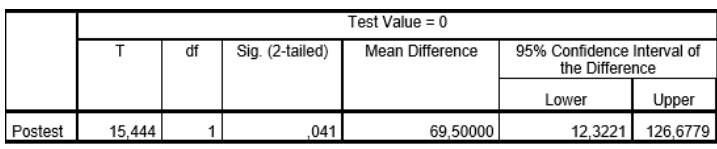

T Hitung $=15,444$

T Tabel $=12.706$

$\mathrm{N}-\mathrm{I}=2-\mathrm{I}=\mathrm{I}$

Hasil uji $\mathrm{t}$ di atas menunjukan bahwa Ho di terima, $t$ hitung dengan nilai 15,444 $>\mathrm{t}$ tabel dengan nilai 12,706 artinya " Layanan konseling individual realitas dengan teknik WDEP untuk pemantapan peminatan pada peserta didik kelas XI MIPA 3 di SMAN-2 Palangka Raya.

Peneliti ini menggunakan konseling individual realitas dengan teknik WDEP untuk pemantapan peminatan peserta didik di SMAN-2 Palangkaraya. Proses penelitian ini dilakukan oleh peniliti sendiri dan pada umunya konselor masih belum mempunyai keterampilan yang memadai untuk menerapkannya. Peneliti dilakukan kepada dua orang peserta didik sebagai subjek. Subjek yang memiliki pemantapan peminatan yang kurang telah teridentifikasi sedang melalui skala pemantapan peminatan. selanjutnya dua orang peneliti diberikan intervensi berupa layanan konseling individual dengan teknik WDEP dilakukan sebanyak 10 kali pertemuan.

Peraturan Menteri Pendidikan Dan Kebudayaan Republik Indonesia (2014:10) Layanan peminatan peserta didik secara khusus ditujukan untuk memberikan kesempatan kepada peserta didik mengembangkan kompetensi sikap, kompetensi pengetahuan, dan kompetensi keterampilan peserta didik sesuai dengan minat, bakat dan/atau kemampuan akademik dalam sekelompok mata pelajaran keilmuan maupun kemampuan dalam bidang keahlian, program keahlian, dan paket keahlian.

Selanjutnya hal ini dapat dilihat dari hasil perolehan skor perhitungan pre-test dan pos-test yang menunjukkan adanya perbedaan setelah diberikan treatment (perlakuan) dari hasil skor pre-test dan pos-test. $\mathrm{Hal}$ ini diartikan pemantapan peminatan dapat ditingkatkan dan teknik WDEP yang digunakan untuk meningkatkan pemantapan peminatan peserta didik.

Dengan demikian dapat dikatakan bahwa hasil yang diperoleh dalam penelitian yang telah dilakukan peneliti terdapat peserta didik kelas XI MIPA 3 di SMAN-2 Palangka Raya tahun pelajaran 2016/2017 bahwa layanan konseling individual realitas dengan teknik WDEP efektif dalam meningkatan pemantapan peminatan peserta didik dengan cara memberikan pandangan mengenai akibatakibat yang akan terjadi jika peserta didik memantapkan peminatannya tersebut.

\section{KESIMPULAN}

Berdasarkan hasil penelitian yang dilakukan oleh peneliti, maka dapat diambil simpulan yaitu : bahwa konseling individual dengan teknik WDEP efektif dalam pemantapan peminatan peserta didik di SMAN-2 Palangkaraya dengan 2 orang siswa 
Jurnal Bimbingan dan Konseling

kelas XI MIPA 3 yang menjadi sampel penelitian, dilihat dari nilai skor Pretest yaitu 45 dan 49 sedangkan nilai Postest yaitu 74 dan 65 jadi selisih skor Pretest dan Postest yaitu 29. 16, untuk nilai hasil uji one sample $t$ test yaitu $t$ hitung $=15,444$ dan $t$ tabel $=12.706$. Maka dari itu perubahan yang dicapai 2.738 di hasil uji $\mathrm{t}$ test. Jadi konseling individual dengan teknik WDEP baik untuk diterapkan pada dunia pendidikan sebagai salah satu bentuk pelayanan bimbingan dan konseling komperhensif disekolah.

\section{DAFTAR PUSTAKA}

$A B K I N$. 20I3. Panduan Khusus Bimbingan Dan Konseling. Pelayanan Arah Peminatan Peserta Didik. Pada Satuan Pendidikan Dasar Dan Menengah (SD/MI, SMP/MTS/SMPLB, SMA/MA/SMALB DAN SMK/MAK). Jakarta.

Panduan Bimbingan dan Konseling Sekolah Menengah Pertama. 20I4. Kementerian Pendidikan Dan Kebudayaan Direktorat Jenderal Pendidikan Dasar. Direktorat Pendidikan Sekolah Menengah Pertama. Jakarta

Peraturan Menteri Pendidikan Dan Kebudayaan Republik Indonesia. Nomor III Tahun 20I4. Bimbingan Dan Konseling pada Pendidikan Dasar Dan Pendidikan Menengah. Pedoman Bimbingan Dan Konseling. 